\title{
RELASI ANTARA KECERDASAN EMOSIONAL DAN KEPUASAN KERJA GURU SMPIT AL-MULTAZAM KUNINGAN
}

\author{
$\lim$ Suryahim* \\ Universitas Islam Al-Ihya (UNISA) Kuningan \\ *Email: iimsuryahim84@gmail.com
}

\begin{abstract}
ABSTRAK
Latar belakang penelitian ini adalah guru sebagai salah satu komponen tenaga pendidik memiliki peranan penting dalam menentukan kelancaran dan keberhasilan penyelenggaraan pendidikan di sekolah. Guru dapat melaksanakan tugas dengan baik, jika ia memiliki kepuasan dalam bekerja yang didukung oleh kecerdasan emosionalnya. Penelitian ini bertujuan untuk mengetahui relasi antara kecerdasan emosional dan kepuasan kerja guru. Jenis penelitian yang digunakan adalah kualitatif dengan desain study kasus. Penelitian dilaksanakan di Sekolah Menengah Pertama Islam Terpadu (SMPIT) Al-Multazam Kuningan. Populasi yang digunakan adalah guru SMPIT Al-Multazam kuningan, dengan teknik pengambilan sampel yaitu teknik sampling jenuh, artinya seluruh populasi digunakan menjadi sampel. Berdasarkan hasil penelitian, kecerdasan emosional memiliki hubungan yang berbanding lurus dengan kepuasan kerja, karena guru yang memiliki tingkat kecerdasan emosional tinggi dapat bekerja dengan penuh rasa tanggung jawab dan memiliki produktifitas tinggi.
\end{abstract}

Kata Kunci: Guru, Kecerdasan Emosional, Kepuasan Kerja. 


\section{PENDAHULUAN}

Sekolah merupakan lembaga pendidikan formal yang memiliki peran penting dan strategis dalam upaya menyiapkan pendidikan. Dalam aspek kualitas pendidikan merujuk kepada makna kualitas proses dan produk. Berdasarkan harapan untuk dapat menghasilkan peserta didik yang handal dan berkualitas, maka kepuasan kerja guru sebagai unsur utama pelaksanaan pendidikan yang dilaksanakan di sekolah harus menjadi prioritas utama. Sebab kepuasan kerja guru merupakan perasaan guru tentang menyenangkan atau tidaknya pekerjaan mereka. Sebagaimana Covey (1997, hlm. 142) menyatakan kepuasan merupakan fungsi dari harapan sekaligus realisasi .

Keberhasilan pendidikan diantaranya dipengaruhi oleh peranan guru dalam melaksanakan pembelajaran. Guru dapat melaksanakan tugas dengan baik, jika ia memiliki kepuasan dalam bekerja yang didukung oleh kecerdasan emosionalnya. Sebagaimana menurut Hasibuan (2002, hlm. 45) bahwa kepuasan kerja adalah sikap emosional yang menyenangkan dan mencintai pekerjaannya. Sikap ini dicerminkan oleh moral kerja, kedisiplinan dan prestasi kerja. Kepuasan kerja ini dinikmati dalam pekerjaan, luar pekerjaan, dan kombinasi dalam luar pekerjaan.

Daniel Goleman (1998, hlm. 4-5) menyatakan, "Kecerdasan emosional merupakan kemampuan merasakan, memahami dan secara efektif merupakan daya kepekaan emosi sebagai sumber energi, informasi koreksi dan pengaruh yang manusiawi". Kecerdasan emosional merujuk kepada kemampuan mengenali perasaan diri sendiri dan perasaan orang lain, kemampuan memotivasi diri sendiri, dan kemampuan mengelola emosi dengan baik pada diri sendiri dan dalam hubungannya dengan orang lain (Goleman, 1997, hlm. 52).

Meilinawati (2001, hlm. 59) menyatakan kecerdasan emosi memiliki hubungan yang sangat signifikan dengan kepuasaan kerja. kepuasaan kerja yang optimal dapat dicapai apabila seseorang memiliki kecerdasan emosional yang tergolong tinggi. Semakin tinggi kecerdasan emosional maka semakin tinggi pula kepuasaan kerja individu. Kepuasaan kerja secara keseluruhan lebih membutuhkan kemampuan menjaga diri agar tetap tenang dan terkendali di bawah himpitan stres dari luar dan dalam diri, kualitas pekerjaan yang menjadi tanggung jawab individu lebih membutuhkan kualitas kemampuan interpersonal yang merupakan bagian dari kecerdasan emosional.

Guru dalam melaksanakan kinerjanya tidak hanya menggunakan kemampuan intelektualnya saja namun juga keterampilan emosional. Kemampuan intelektual lebih dikontrol oleh fungsi inteligensi sedangkan keterampilan emosional lebih dipengaruhi oleh kecerdasan emosional. Kecerdasan emosional yang dimiliki guru akan berperan terhadap penyajian proses pembelajaran. Interaksi edukatif sangat membutuhkan kemampuan guru untuk berempati terhadap anak didik sebagai individu yang unik dengan potensi, masalah dan kemampuan yang berbeda. Kemampuan empati mendorong guru untuk mampu bersikap sesuai kebutuhan tiap anak didik dengan demikian proses pembelajaran dapat berjalan dengan efektif. Proses empati ini membutuhkan kecerdasan emosi yang memadai yang sebaiknya dimiliki oleh guru sehingga tercapai kinerja yang optimal.

\section{METODE}

\section{Metode Penelitian}

Metode yang digunakan dalam penelitian ini adalah kualitatif desain studi kasus (case study) dengan paradigma naturalistik yang berusaha menyelidiki dan mengkonstruksi realitas penelitian apa adanya. Dalam penelitian ini, peneliti dan obyek yang diteliti berinteraksi saling 
mempengaruhi karena penelitian berlangsung dalam kondisi alamiah. Peneliti berusaha untuk memahami realitas objek penelitian secara alamiah sesuai dengan fakta yang terdapat di lapangan. Pendekatan naturalistik merupakan kasus yang digunakan dalam menelaah kasus yang diteliti.

Desain studi kasus memberi kemungkinan untuk menganalisis permasalahan secara teratur dan sistematis sehingga bisa disusun agar mudah dipahami, dan berbagai fakta yang diperlukan untuk menetapkan pilihan strategi, bisa terdeteksi.

\section{Sumber Data}

Sumber utama dalam penelitian kualitatif adalah kata-kata dan tindakan, selebihnya adalah data-data tambahan dokumen dan lain-lain (Moleong, 2009, hlm. 1). Sumber data diperoleh dari pimpinan, guru, karyawan dan siswa SMPIT Al-Multazam. Satuan kajian ini atau unit of analysis dalam penelitian ini adalah pengelola SMPIT Al-Multazam.

\section{Metode Pengumpulan Data}

Pengumpulan data dalam penelitian kualitatif dapat dilakukan oleh peneliti dengan menggunakan beberapa teknik pengumpulan data. Teknik pengumpulan data dalam penelitian kualitatif digunakan melalui observasi berperan serta (participant observation), wawancara mendalam (indepth interview) dan dokumentasi (Iskandar, 2009, hlm. 121).

\section{Analisis Data}

Setelah data dikumpulkan, kemudian dilakukan analisis melalui penerapan model analisis interaktif. Model ini melibatkan tiga komponen yang saling terkait dan menentukan hasil akhirnya, yaitu reduksi data, sajian data dan simpulan atau verifikasi (Miles \& Huberman, 2002, hlm. 22-23).

\section{HASIL DAN PEMBAHASAN}

\section{Kepuasan Kerja Guru SMPIT Al- Multazam}

Kepuasan kerja adalah keadaan emosional yang menyenangkan dari karyawan dalam memandang pekerjaan mereka. Kepuasan kerja mencerminkan perasaan seseorang terhadap pekerjaannya. Hal ini tampak dalam sikap positif karyawan terhadap pekerjaan dan segala sesuatu yang dihadapi di lingkungan kerjanya (Handoko, 2000, hlm. 193). Berdasarkan hasil dari wawancara, dapat dinyatakan bahwa pada umumnya guru SMPIT Al-Multazam merasa puas dengan profesi guru, karena profesi guru dilandasi oleh niat yang tulus, berdasarkan minat, juga adanya perhatian dari pemerintah terkait kesejahteraan berupa sertifikasi, walaupun belum semua guru tersertifikasi. Menurut As'ad (1999, hlm. 101), kepuasan kerja menjadi harapan seorang guru dalam bekerja, karena kepuasan kerja merupakan pernilaian dari pekerja yaitu seberapa jauh pekerjaannya secara keseluruhan memuaskan kebutuhannya.

Minat merupakan bagian dari kepuasan kerja, minat adalah rasa lebih suka dan rasa keterikatan pada suatu hal atau aktivitas, tanpa ada yang menyuruh (Djali, 2011, hlm. 121). Berdasarkan hasil wawancara, menyatakan bahwa minat menjadi guru merupakan keinginan guru tersebut, ini terbukti dengan tugas dan profesi mereka dalam mengajar dilaksanakan secara sungguh-sungguh. Ketika profesi guru sesuai dengan minat, maka tugas guru akan dilakukan disertai rasa senang.

Rasa tentram dalam melaksanakan tugas merupakan indikator dari kepuasan kerja. As'ad (1999, hlm. 101) menyatakan bahwa lingkungan kerja memiliki pengaruh pada kepuasan kerja, sebagaimana konsepsi kepuasan kerja semacam ini melihat hal tersebut sebagai hasil interaksi manusia dengan lingkungan kerjanyadalam kaitan ini rasa tentram guru SMPIT Al-Multazam sebagaimana hasil 
wawancara yaitu kondisi lingkungan kerja yang kondusif menjadikan guru merasa tentram dalam melaksanakan tugasnya, sehingga berdampak pada efektifitas kegiatan belejar mengajar.

Sikap guru terhadap pekerjaan dalam melaksanakan tugas merupakan ukuran dari kepuasan kerja. As'ad (1999, hlm. 101-102) menyatakan bahwa determinasi kepuasan kerja merupakan perasaan orang terhadap pekerjaan tersebut, sekaligus merupakan refleksi dari sikapnya terhadap pekerjaan. Dalam kaitan ini sikap guru terhadap pekerjaandalam melaksanakan tugas sebagaimana hasil wawancara, menyatakan bahwa sikap guru terhadap tugasnya terbentuk atas dorongan internal juga eksternal, dorongan internal seperti dorongan mengajar atas dasar niat ibadah dalam mengajarkan ilmunya. Adapun dorongan eksternal seperti sikap yang terbentuk atas dorongan penilaian untuk menjadi guru teladan.

Bakat guru terhadap profesinya merupakan indikator dari kepuasan kerja. Menurut Goleman (dalam Alex, 1997, hlm. 484) menyatakan bahwa bakat adalah kondisi atau kemampuan yang dimiliki oleh seseorang yang memungkinkannya dengan suatu latihan khusus dapat memperoleh suatu kecakapan dan keterampilan khusus. Atas dasar itu guru harus memiliki bakat terhadap profesinya, sebagaimana hasil wawancara, guru yang tersaring menjadi tenaga pendidik di SMPIT Al-Multazam merupakan guru yang memiliki bakat mengajar yang terpilih setelah proses seleksi penerimaan guru. Bakat mengajar terus berkembang setelah menjadi profesi guru. Kemampuan mengembangkan bakat, akan menjadikan keahliannya terus berkembang.

\section{Kecerdasan Emosional SMPIT Al- Multazam}

Kecerdasan emosional sering diartikan sebagai kecenderungan seseorang untuk menyenangi atau tidak menyenangi sesuatu rangsangan atau objek yang dihadapinya. Kecerdasan emosional berakar pada kecerdasan sosial yang melibatkan kemampuan keterampilan memantau perasaan dan emosi baik pada diri sendiri maupun pada orang lain.

Kecerdasan emosional merujuk kepada kemampuan mengenali perasaan diri sendiri dan perasaan orang lain, kemampuan memotivasi diri sendiri, dan kemampuan mengelola emosi dengan baik pada diri sendiri dan dalam hubungannya dengan orang lain . Dalam hal ini, emosi merujuk pada suatu perasaan dan pikiranpikiran khasnya, suatu keadaan biologis dan psikologis dan serangkaian kecenderungan untuk bertindak.

Cara guru mengatasi kenakalan siswa merupakan indikator dari kecerdasan emosional guru. Cara setiap guru dalam mengatasi kenakalan siswa pasti berbedabeda. Kemampuan ini sangat dituntut untuk dimiliki oleh setiap guru, agar menjadi guru yang profesional. Seorang guru yang mempunyai kecerdasan emosional yang baik maka akan dengan mudah mengatasi kenakalan siswanya, hal ini disebabkan karena ketika guru menemukan siswa yang nakal maka guru tersebut akan menelusuri dari berbagai hal, tidak hanya dari sisi siswa tersebut, tapi menelusuri kepada orang tua, lingkungan trmpat tinggal, teman, dan orang-orang sekitarnya, juga melihat sisi psikologi kejiwaan anak. Setelah itu guru dapat menyimpulkan penyebab kenakalan siswanya, dan mencari solusi yang tepat untuk mengatasinya. Sebagaimana hasil wawancara, cara guru menangani anak yang nakal dapat ditempuh dengan melibatkan pihak sekolah, siswa dan orang tua siswa, sehingga bimbingan dan pengawasan terhadap siswa tidak hanya di sekolah saja, akan tetapi orang tua memiliki tanggung jawab yang sama.

Cara guru meningkatkan semangat dalam melaksanakan tugas merupakan indikator dari kecerdasan emosional guru. Semangat dalam melaksanakan tugas sangat dibutuhkan demi tercapainya tujuan pembelajaran, ketika seorang guru kehilangan semangat dalam mengajar, 
maka tujuan pembelajaranpun akan hilang. Oleh karena itu, guru dituntut untuk dapat menngontrol emosinya agar tetap bersemangat untuk menjalankan tugasnya. Sebagaimana hasil wawancara, memupuk semangat guru dalam mengajar perlu dikembangkan dengan motivasi dari pribadi guru, juga sekolah memiliki andil dalam memotivasinya diantaranya dengan mengadakan training motivasi untuk guruguru, memberikan reward kepada guru yang berprestasi.

Sikap kebersamaan guru dalam mengembangkan mutu sekolah merupakan indikator dari kecerdasan emosional guru. Suatu sekolah tidak akan dinilai sebagai sekolah yang berhasil ketika guru yang berada di lingkungan sekolah tersebut tidak memiliki rasa kebersamaan. Kerja sama seluruh warga sekolah sangat penting terjalin agar mutu sekolah semakin baik, sebagaimana hasil wawancara, untuk mengembangkan kualitas sekolah, diperlukan diperlukan sikap saling membantu dan saling menguntungkan antara guru dengan pihak yayasan. Dari hubungan timbal balik dari kedua belah pihak, akan muncul sikap pro aktif secara bersama-sama dalam mengembangkan kualitas sekolah menjadi sekolah unggulan dan mendapat kepercayaan dari masyarakat.

Rasa senang guru terhadap tugasnya merupakan bagian dari indikator kecerdasan emosional guru. Ketika seorang guru sudah merasakan perasaan senang terhadap tugasnya yaitu mengajar, maka pembelajaran dikelas pun akan terasa lebih bermakna, sehingga tujuan pembelajaran pun akan tercapai. Berdasarkan hasil wawancara, bahwa rasa senang dalam melaksanakan tugas diperoleh melalui sikap menerima terhadap tugas pekerjaannya, kemudian dikerjakan dengan penuh rasa tanggung jawab dan mampu diselesaikan sesuai harapan.

\section{Relasi antara Kepuasan Kerja dan Kecerdasan Emosional Guru SMPIT Al-Multazam}

Meilinawati (2001, hlm. 59) menyatakan bahwa kecerdasan emosi memiliki hubungan yang sangat signifikan dengan kinerja. Kinerja yang optimal dapat dicapai apabila seseorangmemiliki kecerdasan emosi yang tergolong tinggi. semakin tinggi kecerdasan emosi makasemakin tinggi pula kinerja individu. Kinerja secara keseluruhan lebih membutuhkankemampuan menjaga diri agar tetap tenang dan terkendali di bawah himpitan stres dari luar dan dalam diri, kualitas pekerjaan yang menjadi tanggung jawab individu lebih membutuhkan kualitas kemampuan interpersonal yang merupakan bagian dari kecerdasan emosi. Guru dalam melaksanakan kinerjanya tidak hanya menggunakan kemampuan intelektualnya saja namun juga keterampilan emosi. Kemampuan intelektual lebih dikontrol oleh fungsi inteligensi sedangkan keterampilan emosi lebih dipengaruhi oleh kecerdasan emosi. Kecerdasan emosi yang dimiliki guru akan berperan terhadap penyajian proses pembelajaran. Interaksi edukatif sangat membutuhkan kemampuan guru untuk berempati terhadap anak didik sebagai individu yang unik dengan potensi, masalah dan kemampuan yang berbeda. Kemampuan empati mendorong guru untuk mampu bersikap sesuai kebutuhan tiap anak didik dengan demikian proses pembelajaran dapat berjalan dengan efektif. Proses empati ini membutuhkan kecerdasan emosi yang memadai yang sebaiknya dimiliki oleh guru sehingga tercapai kinerja yang optimal.

Terdapat relevansi kecerdasan emosional dengan kepuasan kerja guru SMPIT Al-Multazam. 


\section{KESIMPULAN}

Berdasarkan hasil penelitian maka dapat dirumuskan beberapa kesimpulan sebagai berikut.

1. Kepuasan kerja guru SMPIT Al-Multazam pada umumnya dinilai sudah baik, hal ini ditunjukan oleh hasil penelitian diantaranya, guru merasa puas dengan gaji yang diterima karena dianggap telah memenuhi kebutuhan hidupnya. Guru senang dengan jaminan kerja yang diberikan oleh yayasan berupa tunjangan hari tua dalam bentuk tunjangan pensiun. Guru merasa puas terhadap sistem kerja yang berlaku di SMPIT Al-Multazam sebab dalam pelaksanaan tugas guru lebih diutamakan menciptakan hubungan yang harmonisa, ketentraman dan keikhlasan dalam bekerja. Guru merasa senang dengan status sosial yang dimiliki selain dihormati oleh siswa juga oleh masyarakat. Guru merasa puas atas sistem yang diberlakukan di SMPIT Al-Multazam karena sistem yang berlaku lebih mementingkan kesejahteraan dan kemajuan perkembangan lembaga ke depan. Guru merasa puas dengan mutu manajemen yang diterapkan di SMPIT Al-Multazam.

2. Upaya peningkatan kepuasan kerja guru di SMPIT Al-Multazam dilakukan melalui berbagai cara dan pendekatan yang strategis diantaranya melalui peningkatkan upah, memberikan tunjangan masa kerja, memberikan bantuan pinjaman dana, pembinaan spiritual, peningkatan karir, pemberian kesempatan untuk menempuh studi lanjut. Kegiatan-kegiatan tersebut memberikan kepuasan kerja guru sehingga mampu meningkatkan produktifitas kerja guru.

3. Keadaan kecerdasan emosional guru SMPIT Al-Multazam pada umumnya baik, hal ini ditunjukan oleh keseriusan guru dalam melaksanakan tugasnya dilakukan secara sungguh-sungguh, disiplin dan patuh terhadap peraturan yang berlaku di SMPIT Al-Multazam. Sabar dan tidak tergesa-gesa dalam mengambil keputusan terkait dengan pelaksanaan tugas dan fungsi sebagai guru. Dapat membina hubungan yang harmonis dengan pimpinan, dengan guru dan siswa dalam kegiatan pembelajaran. Dapat berkomunikasi dengan baik dengan pimpinan, dengan guru dan siswa. Memiliki integritas yang tinggi dalam melaksanakan tugas.

4. Upaya pengembangan kecerdasan emosional guru di SMPITAlMultazam melalui pembinaan yang dilakukan sekolah terhadap guru dengan kegiatan-kegiatan yang mampu mengembangkan kecerdasan emosional, seperti training motivasi, pembinaan keagamaan malaui halaqaћ tarbawiyyah, sebuah kajian keagamaan yang dipimpin oleh pembina kajian atau murobbī dan jumlah peserta dibatasi tidak lebih dari 12 orang, kegiatan family gathering yang mana dalam pelaksanaan tersebut guru saling bertukar hadiah. Kegiatan-kegiatan tersebut berdampak positif terhadap pengembangan kecerdasan emosional guru.

Berdasarkan penelitian bahwa kecerdasan emosional memiliki hubungan yang signifikan dengan kepuasan kerja, karena orang yang memiliki tingkat kecerdasan emosional tinggi dapat bekerja dengan penuh rasa tanggung jawab dan produktifitas tinggi. 


\section{REFERENSI}

As'ad. (1999). Psikologi Industri. Yogyakarta: Liberty.

Cooper, R. K., \& Sawat, A. (1998). Kecerdasan Emosional dalam Kepemimpinan dan Organisasi. Jakarta: PT Gramedia Pustaka Utama.

Covey, S. R. (1997). 7 Kebiasaan Manusia yang Sangat Efektif. (Budijanto, Penerj.) Jakarta: Bina Aksara.

Davis, K. (2002). Perilaku dalam Organisasi. (A. Darma, Penerj.) Jakarta: Erlangga.

Djali. (2011). Psikologi Pendidikan. Jakarta: Bumi Aksara.

Goleman, D. (1997). Kecerdasan Emosional Mengapa EQ Lebih Penting daripada IQ. (T. Hermaya, Penerj.) Jakarta: PT Gramedia Pustaka Utama.

Goleman, D. (1998). Kecerdasan Emosional untuk Mencapai Puncak Prestasi. (A. T. Widodo, Penerj.) Jakarta: PT Gramedia Pustaka Utama.

Handoko, T. H. (2000). Manajemen Personalia dan Sumber Daya Manusia. Yogyakarta: BPFE.

Hasibuan, M. S. (2002). Manajemen Sumber Daya Manusia. Jakarta: CV Haji Masagung.

Iskandar. (2009). Metode Penelitian Kualitatif. Jakarta: GP Press.
Kartini, K. (1985). Psikologi Sosial untuk Manajemen, Perusahaan, dan Industri. Jakarta: CV Rajawali.

Meilinawati, P. S. (2001). Hubungan antara Kecedasan Emosional dan Kinerja Karyawan. Indonesian Psychological Journal , 17 (1), 57-62.

Miles, M. B., \& Huberman, A. M. (2002). Analisis Data Kualitatif: Buku Sumber tentang Metode-Metode Baru. Jakarta: UI Press.

Moleong, L. J. (2009). Metode Penelitian Kualitatif. Bandung: Remaja Karya.

Muhadjir, N. N. (2006). Metodologi Penelitian Kualitatif. Yogyakarta: Rake Sarasin.

Saleh, M. (2009). Bekerja dengan Hati Nurani. Jakarta: Erlangga.

Sukmadinata, N. S. (2007). Metode Penelitian Pendidikan. Bandung: PT Remaja Rosdakarya.

Tahang, L. (2010). Peranan dan Fungsi Laboratorium. Maluku: FKIP UNHALU.

Wexley, K. N., \& Yuki, G. A. (2005). Perilaku Organisasi dan Psikologi Personalia. (M. Sobaruddin, Penerj.) Jakarta: Rineka Cipta.

Wibisono, D. (2006). Manajemen Kerja. Jakarta: Erlangga. 